\title{
PHENOTYPIC RESPONSES TO WATER FLOW AND WAVE EXPOSURE IN AQUATIC PLANTS
}

\author{
JÓZEF SZMEJA, AGNIESZKA GAŁKA \\ Department of Plant Ecology, University of Gdańsk \\ Al. Legionów 9, 80-441 Gdańsk, Poland \\ e-mail: biojs@univ.gda.pl
}

(Received: October 16, 2006. Accepted: March 19, 2007)

\begin{abstract}
Plastic responses of 10 aquatic plant species from 5 rivers and 5 lakes in NW Poland were examined. Chara fragilis, C. delicatula, Potamogeton pectinatus, $P$. perfoliatus, $P$. natans, Spirodela polyrhiza, Hydrocharis morsus-ranae, Salvinia natans, Nymphoides peltata and Juncus bulbosus were the subject of research. In the running water of rivers, rhizophytes were generally bigger and they allocated from $0.6 \%$ to $58.6 \%$ more biomass for anchoring in the substrate than in stagnant water (ox bow lakes). In both flow variants rhizophytes allocated a similar biomass fraction for generative reproduction. On the other hand, under the influence of water flow pleustophytes reduced the mass of an individual (Spirodela by 25\%, Hydrocharis 67\%, Salvinia 77\%) and emergent structures $(\mathrm{p}<0.001)$, and the number of sporangia $(\mathrm{p}<0.001)$. In both flow variants the input of biomass to generative reproduction was the same (Salvinia), or it was greater in running water (Hydrocharis; an increase from 4.9 $\pm 1.3 \%$ to $15.1 \pm 3.6 \%)$. Under the conditions of strong wave action, in comparison with the lack of this environmental factor, Chara delicatula was several times shorter $(\mathrm{p}<0.001)$. However, it was also stouter, and as a result it had similar mass. In the areas of wave action the plant allocated $88.8 \%$ of its mass for anchoring in the substrate, whereas when there were no waves, only $22.7 \%$.
\end{abstract}

KEY WORDS: aquatic plants, phenotypic variation, clonal growth, allocation, anchoring structures, current velocity, wave exposure.

\section{INTRODUCTION}

The within-population variability of aquatic macrophytes is caused by environmental pressure, competition and genetic diversity of individuals, which result from many factors including different general-purpose or single-purpose genotypes, sensu Barrett et al. (1993). Genetic diversity of local populations is usually low. However, among populations it is common (Hofstra et al. 1995; Akimoto et al. 1998; Gornall et al. 1998; Gao and Hong 2000). The low level of the former and high of the latter probably arise from asexual reproduction which is widespread in aquatic plants. According to Santamaría (2002), genetic variability of aquatic macrophytes is of rather secondary importance in local populations. If it turned out that such a statement is fully justified, the role of environmental heterogeneity in the plasticity of aquatic plants would acquire new meanings.

In rivers, water flow exerts an important effect on environmental conditions, structure and spatial organisation of vegetation, as well as variability of individuals in populations (Dawson 1988; Allan 1998). In the shallow lake litto- ral, it is wind-induced wave action that plays this part (Hutchinson 1975; Szmeja 1994a-c). Water flow or wave action cause erosion of the substrate or accumulation of matter which is sorted into various granulation fractions (Vermaat et al. 2000). These phenomena are environmental disturbances leading to changes in vegetation structure (Duarte and Kalff 1988; Chambers et al. 1991; Vestergaard and Sand-Jensen 2000) and competitive relations (Kautsky 1991), which is generally manifested by plastic responses in local populations (Szmeja 1994a, b; Idestam-Almquist and Kautsky 1995).

The vast majority of aquatic macrophytes are clonal perennials. Modifications in the construction of a clone's structural units, such as organs of assimilation, reproduction or anchoring, as well as the plasticity of the clone's (individual's) architecture meant as a structural and functional whole, are examples of the clone's phenotypic variability. Structural units participate in various functions of the clone (organism), both general and detailed, such as for example resource uptake and exchange, transfer of assimilates, reproduction or anchoring. What is more, the multiple of units which perform the same function in a clo- 
nal plant cause its higher tolerance of mechanical disturbances in its environment than in the case of a non-clonal plant (Szmeja 2006), which occurs very rarely among aquatic macrophytes. Take, for example, anchoring in the substrate of a clonal individual, which depends on several factors including the number of anchored shoots. However, in non-clonal plants it is only a matter of one anchoring point.

In this work we put forward the hypothesis that plastic responses of clonal plants exposed to wave action in a lake or water flow pressure in a river are adaptations to maintain the occupied area. We will test this hypothesis in the populations of plants growing in a current of not very fast but constantly running rivers, ox bow lakes without water flow, as well as the littoral with frequent wave action and without the influence of this factor.

\section{METHODS}

Generative ramets, i.e. above-ground structures (shoots and thalli) including their anchoring organs (roots, holdfasts, rhizome or stolon), were the subject of our study. Ten species of aquatic macrophytes were taken into consideration: 5 rhizophytes, 2 nymphoids and 3 pleustophytes from 5 lakes (Druzno, Głęboczko, Dybrzk, Krasne, Ostrowite) and 5 rivers (The Brda, The Zbrzyca, The Chocina, The Tuga, The Dzierzgonka) in NW Poland. One hundred mature individuals of Chara fragilis Desv. and the same number of ramets of Potamogeton pectinatus L., $P$. perfoliatus L., P. natans L., Spirodela polyrhiza (L.) Schleid., Hydrocharis morsus-ranae L. and Salvinia natans (L.) All., 50 of each species from running and 50 from stagnant water, were collected in the rivers (700 ramets in total). On the other hand, 100 individuals of each of the following species: Chara delicatula Ag. (=Ch. fragilis Desv. subsp. delicatula A. Br.) and Juncus bulbosus L. as well as ramets of Nymphoides peltata (S.G. Gmel.) Kuntze, including 50 from the littoral exposed to wave pressure and 50 without wave action, were collected in the lakes at a depth of 0.50-0.75 $\mathrm{m}$. In total, 1000 ramets of the afore-mentioned plant species were examined. Each individual (or ramet of a clonal plant), after its height or length had been measured, was divided into above-ground and underground structures, which were later dried to constant weight and weighed.

Characteristics of the aquatic environment in lakes and rivers were described on the basis of water and substrate properties (Table 1). In the water where ramets were collected, current velocity in a river $\left(\mathrm{m} \mathrm{s}^{-1}\right)$, wave velocity in a lake $\left(\mathrm{m} \mathrm{s}^{-1}\right), \mathrm{pH}$, concentrations of total phosphorus (mg $\mathrm{TP} \mathrm{dm}^{-3}$ ) and Kjeldahl nitrogen $\left(\mathrm{mg} \mathrm{N}_{\text {Kjeld. }} \mathrm{dm}^{-3}\right)$, conduc- tivity $\left(\mu \mathrm{S} \mathrm{cm}^{-1}\right)$ and total salt content (mg TDS $\left.\mathrm{dm}^{-1}\right)$ were determined. In the sediment, hydration $(\%)$ and organic matter content $(\%)$ were measured. Current velocity in rivers and wave velocity in lakes were determined on the basis of a mean value from three measurements performed on a one-off basis using a Nautilus C 2000 Sensor current meter. Conductivity and TDS were calculated by means of an LF 95 analyser with a Tetra Con 96 electrode, and pH, using a 320 SET 1 pH-meter. TP concentration was determined after mineralisation with nitric acid by the molybdate colorimetric method with ascorbic acid for $\lambda=690 \mathrm{~nm}$. Kjeldahl nitrogen was assayed converting organic nitrogen to ammonium sulphate. The assays were conducted spectrophotometrically for $\lambda=510 \mathrm{~nm}$ (Hermanowicz et al. 1999; Eaton et al. 2005). The significance of differences between arithmetic means of plant features were tested using ANOVA, Kruskal-Wallis test (Łomnicki 1999) for $\mathrm{p}<0.05$.

\section{RESULTS}

\section{Environmental conditions}

Samples for the variability analysis of ramets of 10 species of aquatic macrophytes came from 5 lowland rivers and 5 lakes ( 2 oligotrophic, 2 mesotrophic and 1 eutrophic). In the rivers, ramets grew in the water with a current velocity of $0.15-0.65 \mathrm{~m} \mathrm{~s}^{-1}$, while in ox bow lakes without flow they occurred at a depth of $0.50-0.75 \mathrm{~m}$. In the rivers and ox bow lakes analysed together, ranges of water properties were as follows: $\mathrm{pH} 7.5-8.1$, TP concentration 0.02$1.0 \mathrm{mg} \mathrm{dm}^{-3}, \mathrm{~N}_{\text {Kjeld. }} 0-3.2 \mathrm{mg} \mathrm{dm}^{-3}$. The total scope of concentrations of these resources in the water was narrow. In the rivers, the substrate was sandy or sandy-gravel (0.3$4.0 \%$ of organic matter), whereas in ox bow lakes it was mineral or mineral-organic (0.8-50.3\%; Table 1$)$.

In the lakes, ramets grew in the shallow littoral with a wave velocity of $0.04-0.15 \mathrm{~m} \mathrm{~s}^{-1}$, and without the influence of this environmental factor, at a depth of 0.50-0.75 m. Ranges of water properties in the lakes were as follows: $\mathrm{pH}$ 7.6-7.9, TP concentration 0.03-1.4 mg dm${ }^{-3}, \mathrm{~N}_{\text {Kjeld. }} 1.0-3.3$ $\mathrm{mg} \mathrm{dm}{ }^{-3}$. Like in the rivers, the range of organic matter content in the substrate was broad (Table 1). It should be mentioned, though, that the given ranges of environmental traits refer to 5 rivers, where 700 ramets of 7 species were collected, as well as 5 lakes (300 ramets of three species). This means that each species under study occurred in a considerably narrower range of environmental conditions than presented in Table 1.

TABLE 1. Features of environments in which aquatic macrophytes occur.

\begin{tabular}{|c|c|c|c|c|}
\hline \multirow{2}{*}{$\frac{\text { Environmental option: }}{\text { Feature (min.-max.) }}$} & \multicolumn{2}{|c|}{ Rivers } & \multicolumn{2}{|c|}{ Lakes } \\
\hline & With flow & Without flow & With wave & Without wave \\
\hline Flow velocity [ $\left.\mathrm{m} \mathrm{s}^{-1}\right]$ & $0.15-0.65$ & 0 & - & - \\
\hline Wave velocity $\left[\mathrm{m} \mathrm{s}^{-1}\right]$ & - & - & $0.04-0.15$ & 0 \\
\hline Water $\mathrm{pH}$ & $7.5-7.8$ & $7.7-8.1$ & $7.8-7.9$ & 7.6-7.9 \\
\hline $\mathrm{TP}$ in water $\left[\mathrm{mg} \mathrm{dm}^{-3}\right]$ & $0.02-0.4$ & $0.2-1.0$ & $0.03-1.4$ & $0.3-1.4$ \\
\hline $\mathrm{N}_{\text {Kjeld }}$. in water $\left[\mathrm{mg} \mathrm{dm}^{-3}\right]$ & $1.3-2.5$ & $1.0-3.2$ & $1.0-3.3$ & $1.0-3.3$ \\
\hline Water conductivity $\left[\mu \mathrm{s} \mathrm{cm}^{-1}\right]$ & $153-557$ & $120-699$ & $97-442$ & $55-442$ \\
\hline Organic matter in sediment [\%] & $0.3-4.0$ & $0.8-50.3$ & $0.8-17.8$ & $1.0-17.8$ \\
\hline Sediment hydration $[\%]$ & $9.6-23.9$ & $13.2-59.6$ & $17.9-75.9$ & $23.3-75.9$ \\
\hline
\end{tabular}



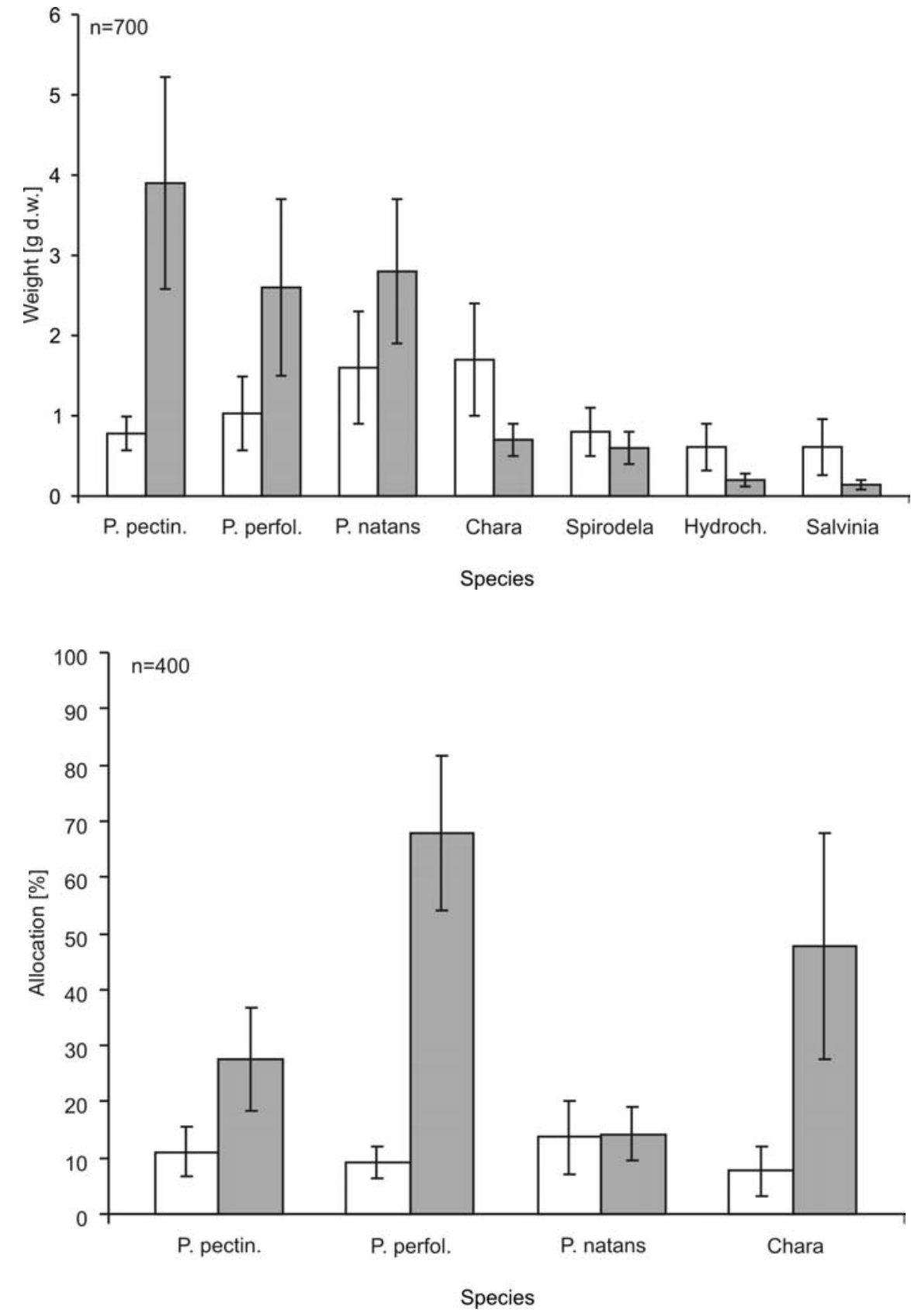

Fig. 1. Weight of Potamogeton pectinatus, $P$. perfoliatus, $P$. natans, Chara fragilis*, Spirodela polyrhiza**, Hydrocharis morsusranae and Salvinia natans individuals in stagnant (white bar) and running water (lined bar). Explanations: * data on the chart $\times 10^{1}$; $* * \times 10^{3}$.
Fig. 2. Biomass allocation to anchoring structures in Potamogeton pectinatus, $P$. perfoliatus, $P$. natans and Chara fragilis in stagnant (white bar) and running water (lined bar).

\section{Phenotypic responses to water flow}

Potamogeton pectinatus: in stagnant water it grows to $36.2 \pm 15.6 \mathrm{~cm}$; its above-ground shoot constitutes $88.9 \%$ of the ramet's mass; the rest $(11.1 \%)$ is made up of anchoring structures (rhizome and roots). In running water the aboveground shoot is several times longer $(112.4 \pm 45 \mathrm{~cm})$, heavier (Fig. 1) and contains $72.4 \%$ of the ramet's mass. This means that in running water, in comparison with the stagnant one, the plant allocates more mass for anchoring in the substrate ( $\mathrm{p}<0.001$; Fig. 2).

Potamogeton perfoliatus: in stagnant water it grows to $84.8 \pm 21.8 \mathrm{~cm}$; the ramet weighs $1.03 \pm 0.46 \mathrm{~g} \mathrm{~d} . \mathrm{w}$.; the above-ground shoot constitutes $90.1 \%$ of the ramet's weight; anchoring organs (underground shoot and roots) make up only $9.1 \%$. In running water the plant is as high (76.9 \pm 44.9 $\mathrm{cm})$, but its weight is twice as heavy as in stagnant water (2.6 \pm 1.1 g d.w.; Fig. 1). Above-ground organs constitute $32.3 \%$ of the ramet's mass, whereas underground ones, $67.7 \%$. This means that in running water an individual al- locates as much as seven times more its mass for anchoring in the substrate than its counterpart growing in stagnant water (Fig. 2). The input of biomass to generative reproduction, determined on the basis of the ratio between inflorescence weight and ramet weight, is similar and amounts to approximately $3 \%$ in both types of environments.

Potamogeton natans: in stagnant water it grows to $173.4 \pm 29.9 \mathrm{~cm}$; the ramet weighs $1.6 \pm 0.7 \mathrm{~g} \mathrm{~d} . \mathrm{w}$.; anchoring organs (stolons and roots) contain $13.7 \%$ of biomass. In the river current the above-ground shoot is longer $(249.7 \pm 42.1 \mathrm{~cm} ; \mathrm{p}<0.05)$ and heavier than the previous one (2.8 \pm 0.9 ; $<<0.05$; Fig. 1). Anchoring organs contain a similar amount of biomass ( $p>0.05$; Fig. 2). This means that, on the one hand, ramets from both compared environments differ in terms of height; on the other hand, their other features are similar ( $\mathrm{p}>0.05)$.

Chara fragilis: in stagnant water it grows vertically (orthotropously) reaching $54.7 \pm 10.4 \mathrm{~cm}$; internodes are $6.6 \pm 0.9 \mathrm{~cm}$ long; an individual weighs $0.17 \pm 0.07 \mathrm{~g}$. Wei- 

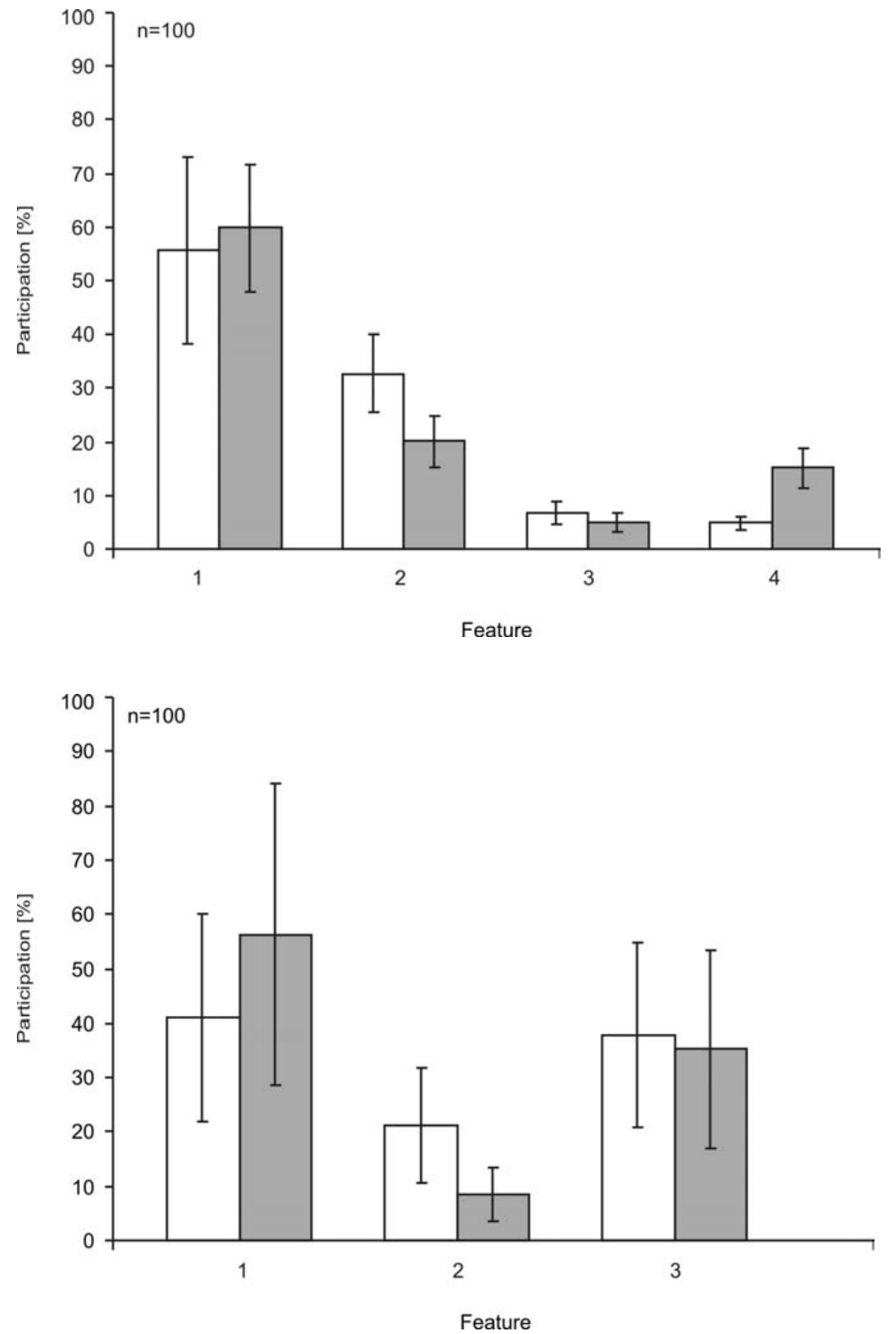

Fig. 3. Participation of emergent (1) and submerged leaves (2), stolon (3) and inflorescence (4) in the mass of a Hydrocharis morsus-ranae individual from stagnant (white bar) and running water (lined bar).
Fig. 4. Participation of emergent (1) and submerged leaves (2), and sporangia (3) in the mass of a Salvinia natans individual from stagnant (white bar) and running water (lined bar). ght of the above-ground part of the thallus is $0.14 \pm 0.05$ g d.w. (92.4\%), while of the underground part, $0.03 \pm 0.02$ g d.w. (7.6\%). In running water the plant grows horizontally (plagiotropously) and is $43.3 \pm 8.8 \mathrm{~cm}$ long, thus it is similar to its counterpart in stagnant water $(p<0.001)$. In running water the part of the thallus which anchors the plant to the substrate contains almost a half of an individual's mass (0.034 g d.w., 47.6\%; Fig. 2). A thallus without chlorophyll, which adheres to the substrate or is set in it, serves for attachment.

Spirodela polyrhiza: in stagnant water it is heavier (an individual's biomass is $0.0008 \pm 0.0003 \mathrm{~g} \mathrm{~d}$.w.) than in running water $(0.0006 \pm 0.0002 \mathrm{~g} \mathrm{d.w}$.; $\mathrm{p}=0.012$; Fig. 1$)$. Differences among the remaining plant features (number of elements and roots, and their weight) are statistically insignificant in both types of environment ( $\mathrm{p}>0.05)$.

Hydrocharis morsus-ranae: in stagnant water the ramet's biomass amounts to $0.61 \pm 0.29 \mathrm{~g} \mathrm{~d}$.w.; emergent lea- ves constitute $55.7 \%$, submerged leaves make up $32.8 \%$, stolons $6.6 \%$, and inflorescence $4.9 \%$. Stolons are $9.5 \pm 2.2$ $\mathrm{cm}$ long. In running water the ramet's weight is $0.20 \pm 0.08$ g d.w. Emergent leaves, submerged leaves, stolons and inflorence make up $59.8 \%, 20.1 \%, 5 \%$ and $15.1 \%$ of this amount, respectively. Stolons are $5.1 \pm 1.3 \mathrm{~cm}$ long. Thus in running water the ramet is three times as light $(\mathrm{p}<0.001$; Fig. 1) and small as previously; its emergent leaves are as heavy $(p>0.05)$, submerged leaves are reduced $(p=0.01)$, and stolons shorter $(\mathrm{p}=0.003)$. The input of biomass to generative reproduction, determined by the ratio between inflorescence weight and ramet weight, is three times as high as in stagnant water ( $<<0.0001$; Fig. 3 ).

Salvinia natans: in stagnant water an individual consists of $4.8 \pm 1.7$ ramets with a total length of $26.2 \pm 10.1 \mathrm{~cm}$. The biomass of an individual amounts to $0.61 \pm 0.35 \mathrm{~g} \mathrm{~d}$.w Emergent and submerged 'leaves', and sporangia constitute $0.25 \pm 0.11 \mathrm{~g} \mathrm{~d} . w$. (41\%), $0.13 \pm 0.07 \mathrm{~g}$ d.w. (21.3\%) and 


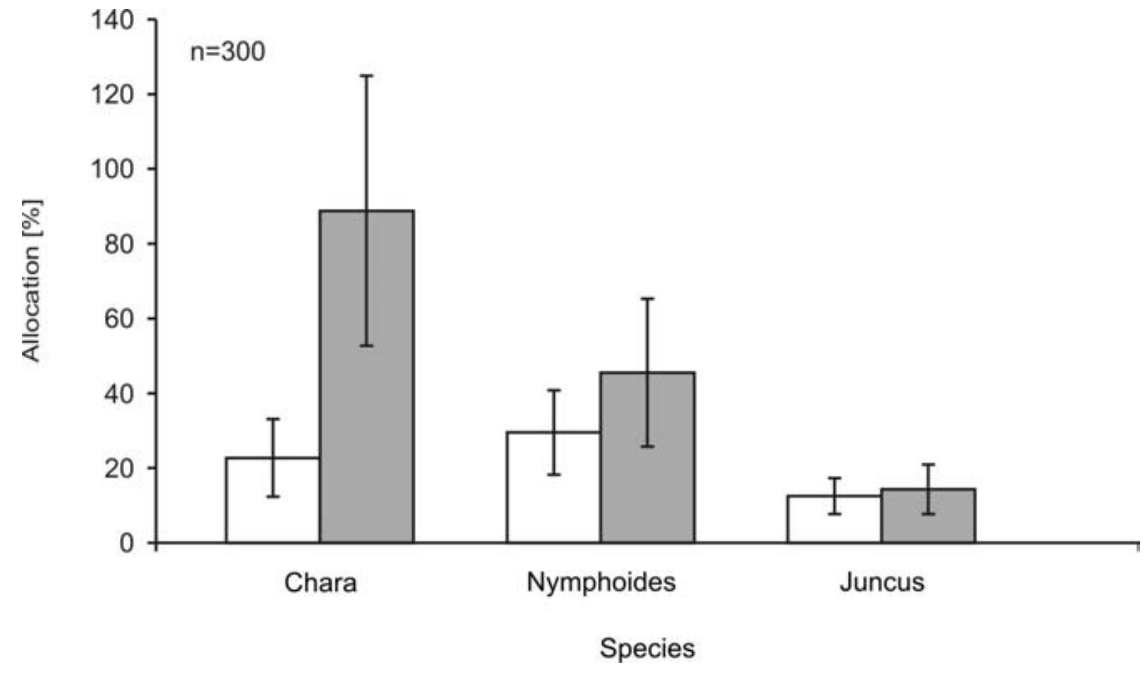

Fig. 5. Biomass allocation to anchoring structures in Chara delicatula, Nymphoides peltata and Juncus bulbosus in water without (white bar) and with wave action (lined bar).
$0.23 \pm 0.13(37.7 \%)$ of this mass, respectively. An individual forms $405.5 \pm 212.6$ sporangia. In running water an individual consists of $2.6 \pm 1.3$ ramets with a total length of $12.5 \pm 6.6 \mathrm{~cm}$. An individual weighs $0.14 \pm 0.06 \mathrm{~g}$ d.w. Emergent and submerged leaves, and sporangia make up $0.08 \pm 0.03$ g d.w. (56.3\%), $0.012 \pm 0.07$ g d.w. (8.5\%) and $0.05 \pm 0.03 \mathrm{~g} \mathrm{~d} . \mathrm{w}$. $(35.2 \%)$ of this weight, respectively. An individual forms $117.9 \pm 90.6$ sporangia. In running water the plant consists of a smaller number of ramets $(p<0.05)$, and is lighter ( $p<0.001$; Fig. 1). Less biomass is accumulated in emergent leaves $(\mathrm{p}<0.001)$, and four times fewer sporangia are formed, but their share in an individual's mass is similar in both types of environment (Fig. 4). This means that the input of biomass to reproduction is similar in them.

\section{The effect of wave exposure on the plasticity of plants}

Chara delicatula: in the littoral of a lake without wave action (a sheltered bay) it grows to a height of $39.1 \pm 10.7$ $\mathrm{cm}$; internodes are $2.9 \pm 0.8 \mathrm{~cm}$ long; an individual's biomass amounts to $0.05 \pm 0.03 \mathrm{~g} \mathrm{~d}$.w. The above-ground part of the thallus weighs $0.04 \pm 0.02 \mathrm{~g} \mathrm{~d} . \mathrm{w}$., and the underground part, $0.01 \pm 0.006 \mathrm{~g} \mathrm{~d}$.w. This means that the plant allocates $22.7 \%$ of its mass for the anchoring in the substrate. The remaining mass $(77.3 \%)$ does not fulfil this function. Where wave action is frequent, the plant is 4.7 times shorter and grows to a height of $6.4 \pm 1.5 \mathrm{~cm}$. However, thalli are thicker and therefore their weight is similar to the one observed in the previous type of environments. When it is in danger of being uprooted from the substrate, virtually the whole mass $(88.8 \%)$ plays the role of an anchor (Fig. 5). A thallus without chlorophyll, which adheres to the substrate or is set in it, serves for attachment.

Nymphoides peltata: in the littoral without wave action the ramet weighs $2.27 \pm 0.9 \mathrm{~g}$ d.w.; emergent leaves, inflorescence, stolons and roots contain $1.2 \pm 0.9 \mathrm{~g} \mathrm{~d} . \mathrm{w}$. (52.9\%), $0.4 \pm 0.1$ g d.w. (17.6\%), $0.6 \pm 0.2$ g d.w. (26.4\%) and $0.07 \pm 0.02 \mathrm{~g} \mathrm{~d} . \mathrm{w} .(3.1 \%)$, respectively. Where wave action is frequent, the ramet's biomass is $2.2 \pm 0.9 \mathrm{~g} \mathrm{~d} . \mathrm{w}$., and in the case of emergent leaves and inflorescence it amounts to $0.9 \pm 0.4 \mathrm{~g} \mathrm{~d} . w .(40.9 \%)$ and $0.3 \pm 0.1 \mathrm{~g} \mathrm{dw}$. (13.6\%), respectively. Statistically significant differences were observed only in the smaller weight of stolons $(0.8 \pm 0.3 \mathrm{~g} \mathrm{~d} . \mathrm{w}$.; $36.4 \%$; $<<0.05)$ and roots $(0.2 \pm 0.1 \mathrm{~g}$ d.w.; $9.1 \%$; $<<0,05)$.
Proportionally to its structure, faced with frequent wave action, the ramet accumulates $16 \%$ more biomass in the anchoring system than in the littoral without wave action (Fig. 5).

Juncus bulbosus: in the place without wave action an individual weighs $0.32 \pm 0.23 \mathrm{~g} \mathrm{~d} . \mathrm{w}$; the above-ground shoot contains $0.23 \pm 0.19 \mathrm{~g} \mathrm{~d}$.w. $(71.9 \%)$, roots, $0.04 \pm 0.03 \mathrm{~g}$ d.w. $(12.5 \%)$ and the tuberous shoot, $0.05 \pm 0.03 \mathrm{~g} \mathrm{d.w.} \mathrm{(15.6 \% ).}$ Under the conditions of strong wave action, an individual's biomass is $0.14 \pm 0.10 \mathrm{~g} \mathrm{~d} . \mathrm{w}$, the above-ground shoot weighs $0.09 \pm 0.07 \mathrm{~g} \mathrm{~d} . \mathrm{w}$. $(64.3 \%)$, roots, $0.02 \pm 0.01 \mathrm{~g}$ d.w. (14.3\%), and the tuberous shoot, $0.03 \pm 0.03 \mathrm{~g} \mathrm{d.w.} \mathrm{(21.4 \% ).}$ This means that, faced with wave action, an individual is smaller, almost twice as light $(\mathrm{p}<0,001)$, but, in comparison with the previous one, it allocates almost the same amount of biomass for attachment ( $\mathrm{p}>0.05$; Fig. 5).

\section{DISCUSSION}

Clonal plants increase the number of above-ground structures, extend the underground ones or shed them bit by bit and add new ones. In this situation it is not a simple task to determine in field observations what is a complete individual, i.e. a structural and functional unity (an organism). In the studies on the within-population variability of clonal plants, entire clones (individuals) are generally not taken into consideration contrary to structural units, i.e. shoots and ramets (modules), sensu Harper (1977, 1986). In our opinion it is advantageous to study the phenotypic and ecological variability of clonal plants considering the ramet, i.e. the above-ground shoot with its root system and a part of rhizome or stolon, to be a comparative unit.

The majority of aquatic macrophytes have a clonal structure and reproduce mainly by vegetative means (Sculthorpe 1967; Grace 1993; Szmeja 2006). On the one hand, this leads to low genetic diversity of a population (Hutchinson 1975; Hofsta et al. 1995; Santamaría 2002). On the other hand, this also results in the fast occupation of space (Szmeja 1994a, b) and considerable phenotypic plasticity which is especially visible in the comparisons of local populations. The qualitative differences in the structure of ramets of the same age above all result from the effect of environmental conditions. Competition, especially within 
a population, is of rather limited importance here, as resources are rarely used up in the aquatic environment (water is a good solvent and carrier of biogenic substances). What is more, communities of aquatic macrophytes have a simple structure, and in a river or in the littoral of a lake there is generally enough free space for occupation (Szmeja 1994a).

Metabolic responses, which result from such phenomena as spatial and temporal diversification of concentrations of the available carbon forms (Sand-Jensen and Gordon 1986; Bowes and Salvucci 1989; Madsen and Sand-Jensen 1991) and other biogenic substances (Spencer et al. 1994, Bazydło and Szmeja 2004; Szmeja and Bazydło 2005), are one of the causes of high phenotypic and ecological variability of macrophytes (Maberly and Spence 1983; Sand-Jensen 1987; Bowes and Salvucci 1989). In a river or lake, stress, sensu Grime (1979), which for example results from extensive and recurrent damage to plants caused by water flow or too intensive or frequent wave action, also plays an important part. Plant populations can react to stressful conditions in many different ways including reduction of their density or biomass. In the case of river plants such responses appear when the flow velocity is above $1.0 \mathrm{~m} \mathrm{~s}^{-1}$ (Chambers et al. 1991). We conducted our studies at a flow velocity of $0.15-0.65 \mathrm{~m} \mathrm{~s}^{-1}$ (modal $0.5 \mathrm{~m} \mathrm{~s}^{-1}$; Table 1), which means that no such reactions probably occurred in populations.

In rivers, we observed a negative relationship between current velocity and such sediment features as TP, $\mathrm{N}_{\text {Kjeld }}$ and organic matter concentrations, and hydration. Similar relationships occurred in the conditions of wave action in the shallow littoral of lakes (Table 1). Current velocity in rivers and wave action in lakes are important factors which regulate the biomass of aquatic macrophytes. According to Westlake (1967), Madsen and Sondergaard (1983), the rate of photosynthesis in aquatic plants is positively correlated only with slow flow (up to $0.02 \mathrm{~m} \mathrm{~s}^{-1}$ ), but its further increase can have a negative effect. As Chambers et al. (1991) write, the relationships between flow and macrophytes may be more complex, e.g. in the populations of species of the genus Ranunculus, flow can favour both expansion and recession of the population. Moreover, in the case of one species (Berula erecta), the size of the ramet may be reduced in its flow gradient. However, in a different species (Mentha aquatica) the value of this feature increased (Puijalon et al. 2005). In addition, biomass allocation to anchoring structures in $M$. aquatica was smaller in the flow gradient, whereas in $B$. erecta the opposite occurred. Results of our research confirm the complexity of the relationship 'flow or wave action - responses of aquatic plants'.

Qualitative differences in the structure of ramets in species collected from rivers appeared at a flow velocity of $0.15 \mathrm{~m} \mathrm{~s}^{-1}$. An increase of flow velocity to $0.65 \mathrm{~m} \mathrm{~s}^{-1}$ does not lead to the emergence of additional qualitative changes in the plant structure. This means that, in the flow or wave action gradient, sediment geochemistry and granulation are rather of secondary importance in the emergence of qualitative changes in the structure of ramets of the same age in the macrophytes under study. Under pressure from wave action or water flow ramets showed qualitatively similar plastic responses, visible for example in the allocation of greater biomass to anchoring organs. Among different plastic responses (see Figs 1-5), we consider this one to be signifi- cant. We will interpret it in the light of the evolutionary trade-off rule. Larger resource allocation to underground anchoring structures enables better attachment of the plant to the substrate, improves the chance of survival and maintenance of the occupied area. We observed this direction of mass allocation in submerged rhizophytes growing on different substrates. We assume then that additional investments in the anchoring structures are a response to mechanical disturbances able to remove the plant from the occupied area.

When Fritz et al. (2004) studied Justicia americana, a riparian emergent plant, they did not observe allocation of more biomass to underground structures along the flow gradient. Puijalon et al. (2005) described a similar type of response in Mentha aquatica. Among the species we studied only in the case of Potamogetom natans (see Fig. 2) and Juncus bulbosus (Fig. 5) there was no increase of allocation to anchoring organs. The emergence of such a pattern of biomass allocation may be compensated for by a stronger shoot structure thanks to which they are more resilient to hydraulic forces.

An increase of ramet weight in rhizophytes (Potamogeton) and a decrease of this value in plants without anchoring structures (see Fig. 1), such as Chara fragilis and three pleustophytes: Spirodela polyrhiza, Hydrocharis morsus-ranae and Salvinia natans, are other responses to water flow. In rhizophytes, the increase of ramet weight results from high investments in anchoring structures. In the river current the above-ground shoots are longer $(P$. pectinatus, $P$. natans) or as long ( $P$. perfoliatus, Ch. fragilis) as beyond the current, i.e. in places with very slow water flow. The elongation of above-ground structures is connected with the effect of greater drag forces (Puijalon et al. 2005), as well as probably with the fixation of a greater amount of resources. However, in rivers the above-ground plant shoots were rarely damaged, probably due to their higher resilience to mechanical influences of hydrodynamic forces.

\section{ACKNOWLEDGEMENTS}

The authors would like to thank their colleagues from the Department of Plant Ecology for their help in field work and Emilia Bochenek for translating this text into English. The study was done within the framework of the project 2 P04G 00127 financed by the State Committee for Scientific Research.

\section{LITERATURE CITED}

AKIMOTO M., SHIMAMOTO Y., MORISHIMA H. 1998. Population genetic structure of wild rice Oryza glumaepatula distributed in the Amazon flood area influenced by its life-history traits. Mol. Ecol. 7: 1371-1381.

ALLAN J.D. 1998. The ecology of running waters. Wyd. Naukowe PWN, Warszawa (in Polish).

BARRETT S.C.H., ECHERT C.G., HUSBAND B.C. 1993. Evolutionary processes in aquatic plant populations. Aquat. Bot. 44: 105-145.

BAZYDŁO E., SZMEJA J. 2004. The effect of pH, dissolved organic carbon and total phosphorus concentrations on selected life history traits of Luronium natans (L.) Raf. Pol. J. Ecol. 52: 191-200.

BOWES G., SALVUCCI M.E. 1989. Plasticity in the photosynthetic carbon metabolism of submersed aquatic macrophytes. Aquat. Bot. 34: 233-266. 
CHAMBERS P.A., PREPAS E.E., HAMILTON H.R., BOTHWELL M.L. 1991. Current velocity and its effects on aquatic macrophytes in flowing waters. Ecol. Appl. 1: 249-257.

CLEVERING O.A, HUNDSCHEID M.P.J. 1998. Plastic and non-plastic variation in growth of newly established clones of Scirpus (Bulboschoenus) maritimus L. grown at different water depths. Aquat. Bot. 62: 1-17.

COOK C.D.K. 1985. Range extensions of aquatic vascular plant species. J. Aquat. Plant Manag. 23: 1-6.

DAWSON F.H. 1988. Water flow and the vegetation of running waters. In: Vegetation of Inland Waters. Symoens J.J. (ed.), Kluwer Academic Publishers, Dordrecht, pp. 283-309.

DUARTE C.M., KALFF J. 1988. Influence of lake morphometry on the response of submerged macrophytes to sediment fertilisation. Can. J. Fish. Aquat. Sci. 45: 216-221.

EATON A.D., CLESCERI L.S., RICE E.W., GREENBERG A.E. 2005. Standard methods for the examination of water and wastewater. Am. Publ. Health Ass., Washington.

FRITZ K.M., EVANS M.A., FEMINELLA J.W. 2004. Factors affecting biomass allocation in the riverine macrophyte Justicia americana. Aquat. Bot. 78: 279-288.

GAO L.Z., HONG S.G.D.Y. 2000. Low levels of genetic diversity within populations and high differentiation among populations of a wild rice, Oryza granulata Nees et Arn. ex Watt., from China. Int. J. Plant Sci. 161: 691-697.

GORNALL R.J., HOLLINGSWORTH P.M., PRESTON C.D. 1998. Evidence for spatial structure and directional gene flow in a population of an aquatic plant, Potamogeton coloratus. Heredity 80: 414-421.

GRACE J.B. 1993. The adaptive significance of clonal reproduction in angiosperms: an aquatic perspective. Aquat. Bot. 44: $159-180$.

GRIME J.P. 1979. Plant strategies and vegetation processes. John Willey, Chichester.

HARPER J.L. 1977. Population biology of plants. Academic Press, London.

HARPER J.L. 1986. Population biology and evolution of clonal organisms. Modules, branches and the capture of resources. Wiad. Ekol. 32: 327-359 (in Polish).

HERMANOWICZ W., DOŻAŃSKA W., DOJLIDO J., KOZIOROWSKI B. 1999. Physico-chemical analysis of water and sewage. Arkady, Warszawa (in Polish).

HOFSTRA D.E., ADAM K.D., CLAYTON J.S., 1995. Isozyme variation in New Zealand populations of Myriophyllum and Potamogeton species. Aquat. Bot. 52: 121-131.

HUTCHINSON G.E. 1975. A Treatise of Limnology. John Wiley \& Sons, New York

IDESTAM-ALMQUIST J., KAUTSKY L. 1995. Plastic responses in morphology of Potamogeton pectinatus L. to sediment and above-sediment conditions at two sites in the northern Baltic proper. Aquat. Bot. 52: 205-216.

KAUTSKY L. 1991. In situ experiments on interrelationships between six brackish macrophyte species. Aquat. Bot. 39: 159-172.

ŁOMNICKI A. 1999. Introduction to statistics for naturalists. Wyd. Nauk. PWN, Warszawa (in Polish).
MABERLY S.C., SPENCE D.H.N. 1983. Photosynthetic inorganic carbon use by freshwater plants. J. Ecol. 71: 705-724.

MADSEN T.V., SAND-JENSEN K. 1991. Photosynthetic carbon assimilation in aquatic macrophytes. Aquat. Bot. 41: 5-40.

MADSEN T.V., SONDERGAARD M. 1983. The effects of current velocity on the photosynthesis of Callitriche stagnalis Scop. Aquat. Bot. 15: 187-193.

PUIJALON S., BORNETTE G., SAGNES P. 2005. Adaptations to increasing hydraulic stress: morphology, hydrodynamics and fitness of two higher aquatic plant species. J. Exp. Bot. 56: 777-786.

SAND-JENSEN K. 1987. Environmental control of bicarbonate use among freshwater and marine macrophytes. In: Plant Life in Aquatic and Amphibious Habitats. Crawford R.M.M. (ed.), Blackwell, Oxford, pp. 99-112.

SAND-JENSEN K., GORDON D.M. 1986. Variable $\mathrm{HCO}_{3}{ }^{-}$affinity of Elodea canadensis Michaux in response to different $\mathrm{HCO}_{3}{ }^{-}$and $\mathrm{CO}_{2}$ concentrations during growth. Oecologia 70: 426-432.

SANTAMARÍA L. 2002. Why are most aquatic plants widely distributed? Dispersal, clonal growth and small-scale heterogeneity in a stressful environment. Acta Oecol. 23: 137-154.

SCULTHORPE C.D. 1967. The biology of aquatic vascular plants. Edward Arnold, London.

SPENCER W.E., TEERI J., WETZEL R.G. 1994. Acclimation of photosynthetic phenotype to environmental heterogeneity. Ecology 75: 301-314.

SZMEJA J. 1994a. An individual's status in populations of isoetid species. Aquat. Bot. 48: 203-224.

SZMEJA J. 1994b. Effect of disturbances and interspecific competition in isoetid populations. Aquat. Bot. 48: 225-238.

SZMEJA J. 1994c. Dynamics of the abundance and spatial organisation of isoetid populations in an oligotrophic lake. Aquat. Bot. 49: 19-32.

SZMEJA J. 2006. A guide to the study of aquatic vegetation. Wyd. UG, Gdańsk (in Polish).

SZMEJA J., BAZYDŁO E. 2005. The effect of water conditions on the phenology and age structure of Luronium natans (L.) Raf. populations. Acta. Soc. Bot. Pol. 74: 253-262.

VERMAAT J.E., SANTAMARÍA L., ROOS P.J. 2000. Water flow across and sediment trapping in submerged beds of contrasting growth form. Arch. Hydrobiol. 148: 549-562.

VESTERGAARD O., SAND-JENSEN K. 2000. Alkalinity and trophic status regulate aquatic plant distribution in Danish lakes. Aquat. Bot. 67: 85-107.

VRETARE V., WEISNER S.E.B., STRAND J.A., GRANÉLI W. 2001. Phenotypic plasticity in Phragmites australis as a functional response to water depth. Aquat. Bot. 69: 127-145.

WESTLAKE D.F. 1967. Some effects of low-velocity currents on the metabolism of aquatic macrophytes. J. Exp. Bot. 55: 187-205 .

WETZEL R.G. 2001. Limnology. Lake and River Ecosystems. 3 ed. Academic Press, San Diego-San Francisco-New York-Boston-London-Sydney-Tokyo. 